\title{
A simple bead-based method for generating cost- effective co-barcoded sequence reads
}

Xiaofang Cheng

Andrei Alexeev

Radoje Drmanac

Xun $\mathrm{Xu}$

Karsten Kristiansen

Jian Wang

Huanming Yang

Snezana Drmanac

Wenwei Zhang

Michelle Wu

Ao Chen

Yan Zou

Fei Fan

Linying Wang

Dan Chen

Han Lam

Robert Chin

Ou Wang ( $\square$ wangou@genomics.cn )

BGI-Shenzhen

Brock Peters ( $\nabla$ bpeters@completegenomics.com )

Advanced Genomics Technology Lab, Complete Genomics Inc.

Method Article

Keywords: stLFR, co-barcoded reads, de novo assembly, haplotyping, NGS

Posted Date: October 11th, 2018

DOI: https://doi.org/10.1038/protex.2018.116

License: (c) (1) This work is licensed under a Creative Commons Attribution 4.0 International License. Read Full License 


\section{Abstract}

Advances in genome sequencing continue to decrease cost and improve quality. However, the diploid information found in most genomes is still lost by the most common sequencing methods. There are several methods currently available for obtaining this haplotype information. However, most of these methods are either time consuming, require expensive equipment and reagents, or both. Here we describe single tube long fragment read $\backslash$ (stLFR), a simple barcoded bead-based process capable of near perfect whole genome variant calling and haplotyping. Our method uses equipment available in nearly all molecular biology laboratories and costs approximately 30 dollars a sample. In addition, the data generated from this process is capable of detecting and phasing structural variations and scaffolding contigs. We expect in the future that this process will enable affordable diploid de novo assembly.

\section{Introduction}

There are currently many methods now available for generating haplotype information $\backslash$ (Zhang et al. 2006; Ma et al. 2010; Fan et al. 2011; Kitzman et al. 2011; Suk et al. 2011; Duitama et al. 2012; Peters et al. 2012; Selvaraj et al. 2013; Amini et al. 2014; Kuleshov et al. 2014; Zheng et al. 2016; Zhang et al. 2017). The majority are based on co-barcoding short sequencing templates originating from long genomic DNA molecules $\backslash$ (Peters et al. 2014), a process first described by Drmanac $\backslash($ Drmanac 2006). We first enabled co-barcoding with the development of long fragment read \(LFR). While the method $\backslash$ (McElwain et al. 2017) was quite useful and resulted in the complete phasing of hundreds of genomes $\backslash$ (Peters et al. 2012; Schaaf et al. 2013; Peters et al. 2015; Ciotlos et al. 2016; Hellner et al. 2016; Mao et al. 2016; Gulbahce et al. ; Walker et al. 2017; Mao et al. 2018), including over 100 from the personal genome project $\backslash$ (Mao et al. 2016), and the accurate sequencing from difficult samples where as few as five cells were available \(Peters et al. 2012; Peters et al. 2015; Hellner et al. 2016; Gulbahce et al. 2017; Mao et al. 2018), it had several limitations. Primarily, each sample was split across a 384 well plate, so processing multiple samples at a time meant handling multiple plates. In addition, because the process relied on multiple displacement amplification, it had base calling bias in regions of high GC base content and sequencing coverage was more variable necessitating $100 \mathrm{X}$ coverage to achieve high quality whole genome variant

calling. Finally, because only 384 compartments were used, this resulted in $10 \%$ of a haploid genome per barcode and limited the phasing N50 length, made it more difficult to detect structural variations, and made de novo assembly impossible. Here we introduce a method called single tube long fragment read $\backslash($ stLFR). This process was first proposed by us in a patent application \(Drmanac 2013) and a similar, but limited implementation of this method was published by Zhang et al. \(Zhang et al. 2017). Like the LFR process described above stLFR utilizes the concept of co-barcoding short reads belonging to a long DNA fragment. Unlike LFR, the stLFR process uses the surface of micron sized magnetic beads as compartments and as the name suggests this process take place in a single tube. In a typical stLFR experiment 10-50 million beads are used. Each bead contains hundreds of thousands of copies of the same barcode and there are a total of 3.6 billion different barcodes. This means in an stLFR sample there is practically no overlap between barcode sequences. Also, because only 1-10 ngs of genomic DNA is 
used, most beads capture less than 10 long DNA molecules. For de novo assembly applications it is possible to achieve over $80 \%$ of long DNA fragments having sequencing reads co-barcoded by a unique barcode $\backslash$ (captured by a single bead) by using $1 \mathrm{ng}$ of DNA and 50 million beads. stLFR is a simple process that can be performed without any special equipment. The process begins by inserting a transposon with a capture sequence at a regular interval along the genomic DNA molecules. These transposons inserted DNA molecules are then added to barcode labeled $3 \mu \mathrm{M}$ magnetic beads that contain a complementary sequence to the capture sequence on the transposon. After hybridization, the barcode is transferred to the transposon sequence through a ligation step. At this point two different methods can be used. The first and the simplest is to directly PCR amplify using primers to the transposon sequences followed by analysis on a next generation sequencing $\backslash$ (NGS) platform. If more coverage of each original long genomic DNA molecule is desired an additional ligation step with another adapter sequence can be performed followed by PCR and sequencing. Both methods are described in detail in the following protocol. A full analysis of stLFR data was performed by Wang et al. (Wang et al. 2018).

\section{Reagents}

$1 \mathrm{~Kb}$ Plus DNA Ladder $\backslash($ ThermoFisher, cat. no. 10787018) 100Kd MWCO Biotech CE dialysis tubing $\backslash$ (Spectrum Labs, cat. no. 131486) 384-well Armadillo PCR plate \(ThermoFisher, cat. no. AB2384) Agencourt $\circledast$ AMPure XP beads $\backslash($ Beckman Coulter, cat. no. A63882) APE $1 \backslash(10,000$ units $/ \mathrm{mL}) \backslash(\mathrm{New}$ England Biolabs, cat. no. M0282L) ATP \(100 mM) \(Teknova, cat. no. A1210) Barcoded bead construction oligonucleotides $\backslash($ IDT $) \backslash$ (see note) Betaine $\backslash(5 \mathrm{M}) \backslash$ (Sigma-Aldrich, cat. no. B0300-5VL) BSA $\backslash(20 \mathrm{mg} / \mathrm{mL}) \backslash($ New England Biolabs, cat. no. B9000S) Common adapter oligonucleotides $\backslash($ IDT $)$ DMF $\backslash$ $(\sim 100 \%) \backslash($ Sigma-Aldrich, cat. no. D4551-250ML) DMSO \(100\%) \(Sigma-Aldrich, cat. no. D9170-5VL) dNTPs $\backslash(25 \mathrm{mM}) \backslash($ ThermoFisher, cat. no. R1121) Dialysis tubing $\backslash(1,000 \mathrm{kD}$ MWCO $) \backslash($ Spectrum Laboratories, Inc., cat. no. 131486) DTT (Sigma-Aldrich, cat. no. 11583786001) Dynabeads ${ }^{\mathrm{TM}} \mathrm{M}-280$ Streptavidin \(ThermoFisher, cat. no. 60210) EDTA \(0.5 M, pH 8.0) \(Sigma-Aldrich, cat. no. 03690$100 \mathrm{ML}) \mathrm{ET}$ SSB $\backslash(500 \mu \mathrm{g} / \mathrm{ml}) \backslash($ New England Biolabs, cat. no. M2401S) Exonuclease I $\backslash(20,000$ units/mL) \(New England Biolabs, cat. no. M0293L) Exonuclease III $\backslash(100,000$ units/mL) $($ New England Biolabs, cat. no. M0206L) Formamide $\backslash(100 \%, 250 \mathrm{~mL}) \backslash($ Sigma-Aldrich, cat. no. 47671-250ML-F) Glycerol \(100\%) \(Sigma-Aldrich, cat. no. G5516-100ML) KCl \(Sigma-Aldrich, cat. no. P9333-1KG) KH2PO4 \(Sigma-Aldrich, cat. no. 795488-1KG) KOH \(Sigma-Aldrich, cat. no. P5958-1KG) MgCl2 \(1 M) \ (Sigma-Aldrich, cat. no. 63069-500ML) MgSO4 \(1 M) \(Sigma-Aldrich, cat. no. M3409-100ML) MicroAmp Clear Adhesive Film \(ThermoFisher, cat. no. 4306311) NaCl $\backslash(5 \mathrm{M}) \backslash($ ThermoFisher, cat. no. AM9760G) Na2HPO4 \(Sigma-Aldrich, cat. no. S7907-1KG) NaOH \(10M) \(Sigma-Aldrich, cat. no. 72068$100 \mathrm{ML})$ NEB2 Buffer $\backslash(10 X) \backslash$ (New England Biolabs, cat. no. B7002S) PEG-8000 \(50\%) \(Rigaku, cat. no. 1008063) Pfu Turbo Cx Hotstart DNA Polymerase \(Agilent, cat. no. 600414) Proteinase K, recombinant, PCR grade solution $\backslash(14-22 \mathrm{mg} / \mathrm{mL}) \backslash($ Roche, cat. no. 03115844001) RiboRuler Low Range RNA Ladder $\backslash$ (Thermofisher, cat. no. SM1831) RNase-IT ribonuclease cocktail \(Agilent, cat. no. 400720) SDS $\backslash(10 \%) \backslash$ (ThermoFisher, cat. no. 15553027) Sucrose \(Sigma-Aldrich, cat. no. S7903-1KG) T4 DNA ligase \(2x106 
units/mL) \(New England Biolabs, cat. no. M0202M) TA Buffer $\backslash(10 X) \backslash($ Teknova, cat. no. T0379) TAPS$\mathrm{NaOH} \backslash(1 \mathrm{M}, \mathrm{pH}$ 8.5) \(Boston BioProducts, cat. no. BB-2375) TBE $\backslash(10 X) \backslash($ ThermoFisher, cat. no. 15581028) TE Buffer $\backslash(10 X) \backslash$ (Fisher Scientific, cat. no. BP24771) Tn5 enzyme $\backslash$ (see note) Transposon oligonucleotides $\backslash($ IDT $)$ Tris-HCl $\backslash(1 \mathrm{M}, \mathrm{pH} 7.5) \backslash($ ThermoFisher, cat. no. 15567027) Tris-HCl $\backslash(2 \mathrm{M}, \mathrm{pH} 7.8)$ $\backslash\left(\right.$ Amresco, cat. no. J837-500ML) Triton ${ }^{\text {TM }}$ X-100 \(10\%) \(Sigma-Aldrich, cat. no. 93443-100ML) TWEEN® $20 \backslash(10 \%) \backslash$ (Roche, cat. no. 11332465001) UDG $\backslash(5,000$ units/mL) \(New England Biolabs, cat. no. M0280L) Reagent Setup 3' Branch Ligation Buffer $\backslash(3 X) 6 \mathrm{~mL}$ of 50\% PEG-8000 $0.75 \mathrm{~mL} 2 \mathrm{M}$ Tris-HCl $\backslash$ (pH 7.8) $0.3 \mathrm{~mL} 1 \mathrm{M} \mathrm{MgCl} 20.3 \mathrm{~mL} 0.1 \mathrm{M}$ ATP $15 \mu \mathrm{L} 1 \mathrm{M}$ DTT $75 \mu \mathrm{L} 20 \mathrm{mg} / \mathrm{mL}$ BSA $2.560 \mathrm{~mL}$ of sterile $\mathrm{dH} 2 \mathrm{O}$ Store at $-20^{\circ} \mathrm{C}$ for 1 year. Annealing Buffer $\backslash(3 \mathrm{X}) 3 \mathrm{~mL}$ of $1 \mathrm{M}$ Tris-HCl, $\mathrm{pH} 7.56 \mathrm{~mL}$ of $5 \mathrm{M} \mathrm{NaCl} 91$ $\mathrm{mL}$ of sterile $\mathrm{dH} 2 \mathrm{O}$ Store at room temperature for 1 year. Buffer $\mathrm{D} \backslash(10 \mathrm{X}) 224 \mathrm{mg}$ of KOH $50 \mu \mathrm{L}$ of $0.5 \mathrm{M}$ EDTA $2.45 \mathrm{~mL}$ of sterile $\mathrm{dH} 2 \mathrm{O}$ Make aliquots and store at $-20^{\circ} \mathrm{C}$ for 1 month. Coupling Buffer $\backslash(1 \mathrm{X}) 5 \mathrm{~mL}$ of $1 \mathrm{X}$ TE $5 \mathrm{~mL}$ of $100 \%$ glycerol Store at $-20^{\circ} \mathrm{C}$ for 1 year. Digestion Buffer $\backslash(1 \mathrm{X}, \mathrm{pH} 8.0) 1.75 \mathrm{~g}$ of $\mathrm{Na} 2 \mathrm{HPO} 40.2 \mathrm{~g}$ of KCl $0.2 \mathrm{~g}$ of KH2PO4 $27.4 \mathrm{~mL} 5 \mathrm{M} \mathrm{NaCl} 20 \mathrm{~mL}$ of $0.5 \mathrm{M}$ EDTA $\backslash(\mathrm{pH}$ 8.0) $800 \mathrm{~mL}$ of sterile $\mathrm{dH} 2 \mathrm{O}$ Adjust the $\mathrm{pH}$ to 8.0 with $1 \mathrm{M} \mathrm{NaOH}$. Add sterile $\mathrm{dH} 2 \mathrm{O}$ to a final volume of 1 liter. Filter sterilize. Store at room temperature for 1 year. High-Salt Bead Binding Buffer $\backslash(1 \mathrm{X}) 5 \mathrm{~mL}$ of $1 \mathrm{M}$ Tris-HCl $\backslash$ $(\mathrm{pH} 7.5) 6 \mathrm{~mL}$ of $5 \mathrm{M} \mathrm{NaCl} 20 \mu \mathrm{L}$ of $0.5 \mathrm{M}$ EDTA $88.98 \mathrm{~mL}$ of sterile dH2O Store at room temperature for 1 year. High-Salt Wash Buffer $\backslash(1 \mathrm{X}) 5 \mathrm{~mL}$ of $1 \mathrm{M}$ Tris-HCl, pH $7.510 \mathrm{~mL}$ of $5 \mathrm{M} \mathrm{NaCl} 20 \mu \mathrm{L}$ of $0.5 \mathrm{M}$ EDTA $0.5 \mathrm{~mL}$ of $10 \%$ TWEEN ${ }^{\circledR} 2084.48 \mathrm{~mL}$ of sterile $\mathrm{dH} 20$ Store at room temperature for 1 year. Hybridization Buffer $\backslash(1 \mathrm{X}) 50 \mathrm{~mL}$ of $1 \mathrm{M}$ Tris-HCl, pH $7.5100 \mathrm{~mL}$ of $1 \mathrm{M} \mathrm{MgCl} 25 \mathrm{~mL}$ of $10 \%$ TWEEN® $20845 \mathrm{~mL}$ of Water Store at room temperature for 1 year Ligation Buffer $\backslash(10 X) 25 \mathrm{~mL}$ of $50 \%$ PEG-8000 $12.5 \mathrm{~mL}$ of 2 M Tris-HCl $\backslash(\mathrm{pH} 7.8) 5 \mathrm{~mL}$ of $100 \mathrm{mM}$ ATP $5 \mathrm{~mL}$ of $1 \mathrm{M} \mathrm{MgCl} 22.5 \mathrm{~mL}$ of sterile dH2O Store at $-20^{\circ} \mathrm{C}$ for 1 year. Ligation Buffer, No MgCl2 \(10X) $25 \mathrm{~mL}$ of 50\% PEG-8000 $12.5 \mathrm{~mL}$ of $2 \mathrm{M}$ Tris-HCl $\backslash(\mathrm{pH} 7.8) 5 \mathrm{~mL}$ of $100 \mathrm{mM}$ ATP $5 \mathrm{~mL}$ of $1 \mathrm{M} \mathrm{DTT} 2.5 \mathrm{~mL}$ of sterile dH2O Store at $-20^{\circ} \mathrm{C}$ for 1 year. Low-Salt Wash Buffer $\backslash(1 X) 5 \mathrm{~mL}$ of $1 \mathrm{M}$ Tris-HCl, pH $7.53 \mathrm{~mL}$ of $5 \mathrm{M} \mathrm{NaCl} 0.5 \mathrm{~mL}$ of $10 \%$ TWEEN® $2091.5 \mathrm{~mL}$ of sterile dH2O Store at room temperature for 1 year. Lysis Buffer $\backslash(1 \mathrm{X}, \mathrm{pH} 8.3) 0.22 \mathrm{~g}$ of $\mathrm{KCl} 120 \mathrm{~g}$ of sucrose $13 \mathrm{~mL}$ of 1 M Tris- $\mathrm{HCl} \backslash(\mathrm{pH} 7.5) 2 \mathrm{~mL}$ of $0.5 \mathrm{M}$ EDTA $\backslash(\mathrm{pH} 8.0) 28 \mathrm{~mL}$ of $5 \mathrm{M} \mathrm{NaCl} 10 \mathrm{~mL}$ of Triton® X-100 $800 \mathrm{~mL}$ of sterile $\mathrm{dH} 2 \mathrm{O}$ Adjust the $\mathrm{pH}$ to 8.3 Add sterile $\mathrm{dH} 2 \mathrm{O}$ to a final volume of 1 liter Filter sterilize Store at $4{ }^{\circ} \mathrm{C}$ for 1 year. SSB binding buffer $\backslash(1 \mathrm{X}) 0.5 \mathrm{~mL}$ of $1 \mathrm{M}$ Tris- $\mathrm{HCl} \backslash(\mathrm{pH} 7.5) 0.2 \mathrm{~mL}$ of $1 \mathrm{M} \mathrm{MgCl} 29.3 \mathrm{~mL}$ of sterile dH2O Store at $-20^{\circ} \mathrm{C}$ for 1 year. Transposase Buffer $\backslash(5 X) 0.5 \mathrm{~mL}$ of $1 \mathrm{M}$ TAPS-NaOH $\backslash(\mathrm{pH} 8.5)$ $0.25 \mathrm{~mL}$ of $1 \mathrm{M} \mathrm{MgCl} 25 \mathrm{~mL}$ of $100 \%$ DMF $4.25 \mathrm{~mL}$ of sterile dH2O Store at $-20{ }^{\circ} \mathrm{C}$ for 1 year. PfuCx mix $\backslash$ (2X) $2 \mathrm{~mL}$ of $10 \mathrm{X}$ PfuCx buffer $\backslash$ (included with enzyme) $0.5 \mathrm{~mL}$ of $100 \%$ DMSO $2 \mathrm{~mL}$ of $5 \mathrm{M}$ Betaine 60 $\mu \mathrm{L}$ of $1 \mathrm{M}$ MgSO $4240 \mu \mathrm{L}$ of $25 \mathrm{mM}$ dNTPs $5.2 \mathrm{~mL}$ of sterile dH2O Notes Tn5 enzyme preparation Tn5 was prepared following the protocol outlined in Picelli et al. \(Picelli et al. 2014). Tn5 enzyme is also commercially available from Lucigen $\backslash$ (cat. no. TNP92110) but requires the acceptance of Illumina's license acknowledgment. Barcoded bead construction oligos Oligonucleotide sequences are available in Supplementary Materials. All barcoded oligonucleotides were synthesized at $100 \mathrm{nmol}$ scale in 384 well format with standard desalting and delivered at a concentration of $200 \mu \mathrm{M}$ in $1 \mathrm{X} T \mathrm{TE} \backslash(\mathrm{pH} 8.0)$ by Integrated DNA Technologies $\backslash($ Coralville, IA). There are a total of 1,536 unique barcode oligos for each barcode set and there are 3 barcode sets. This enables up to $~ 3.6$ billion different barcode combinations. This may be more than necessary for some applications and less barcode combinations can be achieved 
by ordering less plates of oligonucleotides. This particular design does require that at least one barcode oligo from each set is used to create the proper final sequence, however, slight modifications of the 6 base overlapping sequences between barcode sets can be made to remove an entire barcode set.

\section{Equipment}

2.4 $\mathrm{L}$ tall polystyrene container $\backslash\left(\right.$ Click Clack, cat. no. 659030) or equivalent DynaMag ${ }^{\mathrm{TM}}-2$ Magnet $\backslash$ (ThermoFisher, cat. no. 12321D) Easy 50 EasySep $^{\text {TM }}$ Magnet $\backslash($ Stem Cell Technologies, cat. no. 18002) or equivalent Lab oven capable of holding Tube Revolver/Rotator Magnetic plate stirrer Medium sized magnetic stir bar Standard lab vortexer Tetrad PCR thermocycler \(Bio-Rad, cat. no. PTC0240) or equivalent capable of $100 \mu \mathrm{L}$ per well reaction volumes Tube Revolver/Rotator $\backslash$ (Thermo Fisher, cat. no. 88881001 ) or equivalent

\section{Procedure}

High Molecular Weight DNA isolation from cells This method is based on the RecoverEase ${ }^{\mathrm{TM}}$ DNA isolation kit protocol $\backslash$ (Agent Technologies 2015), but is performed using much larger volumes so as to reduce the viscosity of the resulting solution. 1 . Pellet up to $1 \times 107$ dispersed nucleated cells in a 15 or $50 \mathrm{~mL}$ conical tube $\backslash(500 \mathrm{xg}$ for $5 \mathrm{~min})$. Remove supernatant. Add $500 \mu \mathrm{L}$ of lysis buffer to the cell pellet and vortex sample briefly for 3-5 seconds on medium speed and place the conical tube in refrigerator for $\sim 10$ minutes, swirling occasionally. 2. Prepare proteinase K solution by combining $250 \mu \mathrm{L}$ of $10 \%$ SDS, $250 \mu \mathrm{L}$ of Proteinase $\mathrm{K}$, and $4 \mathrm{~mL}$ of $1 \mathrm{X}$ TE. Place on $50^{\circ} \mathrm{C}$ heat block and warm briefly $\backslash(\sim 5$ minutes). 3. Prepare the digestion solution by combining $20 \mu \mathrm{L}$ of RNase-lt ribonuclease cocktail with $4 \mathrm{~mL}$ of digestion buffer. 4 . Add $\sim 4 \mathrm{~mL}$ of the prepared digestion solution to the lysed cells and buffer from step one and gently rock the conical tube. 5 . Place the conical tube in a $50^{\circ} \mathrm{C}$ heat block after 5 minutes add $4.5 \mathrm{~mL}$ of the warmed proteinase $\mathrm{K}$ solution to the free-floating pellet. Swirl the conical tube gently to mix. 6. Recap the tube and incubate in a $50{ }^{\circ} \mathrm{C}$ heat block for 2 hours, swirling the tube gently every 30 minutes. 7. Cut approximately $13 \mathrm{~cm}$ of dialysis tubing $\backslash$ (it has a capacity of approximately $1 \mathrm{~mL} / \mathrm{cm}$ ). Allow to equilibrate in $0.5 X$ TE for 30 minutes. Seal one end with a dialysis clip. 8. Pour at least $1 \mathrm{~L}$ of $0.5 X$ TE buffer into a dialysis reservoir. 9. Carefully pour viscous genomic DNA from the conical tube into the open end of dialysis tubing. Seal open end of dialysis tubing with dialysis clip. Attach float to one clip. Place dialysis tubing with float into dialysis reservoir. 10. Dialyze the genomic DNA at room temperature for 24 to 48 hours while stirring the buffer gently with a magnetic stir bar. Replace the TE buffer once during the dialysis period to maximize the purity of the recovered DNA. 11. Upon completion of dialysis, remove the dialysis tubing from TE buffer, remove the float and clip from the top of the dialysis tubing and gentle pour into a $15 \mathrm{~mL}$ conical tube. DNA can be used immediately without shearing. Barcoded beads Barcoded beads are constructed using a split and pool strategy with 3 sets of double-stranded barcode DNA molecules. Full length adaptors are constructed through successive ligations $\backslash$ (Figure 1 and Supplementary Figure 1). Barcode oligonucleotides are supplied in 384-well plates $\backslash$ (see Reagents Notes). Common adapter oligo nucleotides are supplied in tubes. Depending on 
what sequencing technology is being used, it may be necessary to alter the PCR primer sequence within the common adapter oligo. 12. Mix $10 \mu \mathrm{L}$ of complementary oligonucleotide from each well of the source 384-well plates in 384-well PCR plates with $10 \mu \mathrm{L} 3 X$ Annealing Buffer. Mix $30 \mu \mathrm{L}$ of common adapter oligonucleotides in one well of an 8-wel PCR strip tube. 13. Incubate at $70^{\circ} \mathrm{C}$ for 3 minutes followed by a slow ramp of $0.1^{\circ} \mathrm{C} / \mathrm{s}$ to $20^{\circ} \mathrm{C}$ on a PCR thermocycler. Hybridized barcode oligonucleotides have a final concentration of $66 \mu \mathrm{M}$. 14. Mix $4.725 \mathrm{~mL} \backslash(157.5 \mu \mathrm{mol})$ of hybridized Bead Linker containing a $5^{\prime}$ dualbiotin with $3.225 \mathrm{~mL}$ of Ligation Buffer $\backslash(10 \mathrm{X}), 460.8 \mu \mathrm{L} \backslash(921,600$ units $)$ of T4 DNA Ligase, and $9.67 \mathrm{~mL}$ $\mathrm{dH} 2 \mathrm{O}$ to a total volume of $18.081 \mathrm{~mL}$. 15. Dispense $11.2 \mu \mathrm{L}$ of the ligation mixture into each well of four new 384-well PCR plates. Then add $8.8 \mu \mathrm{L} \backslash(580 \mathrm{pmol})$ from each well of the hybridized first barcode plates to each well containing the bead linker ligation mixture. Seal with MicroAmp Clear Adhesive Film, vortex, centrifuge, and incubate at room temperature for 1 hour. 16 . Collect 100 billion $\backslash(143 \mathrm{~mL})$ of $\mathrm{M}$ 280 streptavidin coated magnetic beads by transferring $50 \mathrm{~mL}$ beads into empty $50 \mathrm{~mL}$ centrifuge tube. Place the $50 \mathrm{~mL}$ tube with beads in the Easy 50 EasySep $^{\text {TM }}$ Magnet for 5 minutes to collect beads to the side of the tube. Carefully remove supernatant by pipette. Transfer a second $50 \mathrm{~mL}$ beads into tube on magnet. Let sit for 5 minutes on magnet and carefully remove supernatant. Transfer a final $43 \mathrm{~mL}$ of beads to the $50 \mathrm{~mL}$ tube. Let sit for 5 minutes on magnet and carefully remove supernatant. Wash beads twice with Low-Salt Wash Buffer then resuspend well in $8 \mathrm{~mL}$ of High-Salt Bead Binding Buffer. 17. Dispense $5 \mu \mathrm{L}$ of beads in High-Salt Bead Binding Buffer to each well of the plates containing ligation product. Vortex the beads source tube occasionally during dispensing to keep the beads well-suspended. 18. Seal plates with MicroAmp Clear Adhesive Film, vortex, and place onto the tube revolver for incubation at room temperature for 1 hour on "oscillating" mode. 19. Centrifuge plates at $300 \mathrm{xg}$ for 5 seconds to remove beads from seal, but not allow a pellet to form. Remove seal and add $2.8 \mu \mathrm{L} 0.1 \%$ SDS to each well. Seal plates again with MicroAmp Clear Adhesive Film, vortex briefly and incubate at room temperature for 10 minutes. 20. Vortex and then centrifuge plates at $300 \mathrm{xg}$ for 5 seconds to remove beads from the plate seal. Remove the seal from each plate and invert plates onto a collection tray. Centrifuge at $500 \mathrm{xg}$ for 2 minutes. Using a $10 \mathrm{~mL}$ serological pipette, collect beads into one new $50 \mathrm{~mL}$

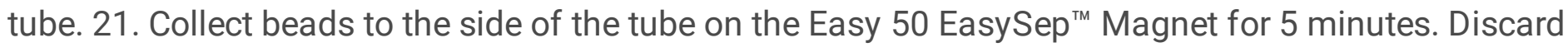
supernatant. Wash once with $10 \mathrm{~mL}$ of High Salt Wash Buffer and then twice with Low-Salt Wash Buffer. Resuspend beads $8 \mathrm{~mL} 1 \mathrm{XLigation}$ Buffer. 22. Dispense $5 \mathrm{ul}$ of beads into each well of four new 384-well PCR plates. Vortex the beads source tube occasionally during dispensing to keep the beads wellsuspended. 23. To ligate the second set of barcodes, make a mixture containing $3.225 \mathrm{~mL}$ Ligation Buffer $\backslash(10 X), 460.8 \mu \mathrm{L} \backslash(921,600$ units $)$ of T4 DNA Ligase, and $6.33 \mathrm{~mL} \mathrm{dH2O} \mathrm{to} \mathrm{a} \mathrm{total} \mathrm{volume} \mathrm{of} 10.02 \mathrm{~mL}$. Dispense $6.2 \mu \mathrm{L}$ of the second ligation mixture to each well of the four 384-well PCR plates containing beads. Next add $8.8 \mu \mathrm{L} \backslash(580 \mathrm{pmol})$ from each well of the hybridized second barcode plates to the corresponding wells of the 384-well PCR plates containing the bead and ligation mixture. 24. Repeat steps 18-22. 25. To ligate the third set of barcodes, make a ligation mixture containing $3.225 \mathrm{~mL}$ Ligation Buffer $\backslash(10 \mathrm{X}), 460.8 \mu \mathrm{L} \backslash(921,600$ units $)$ of T4 DNA Ligase, and $6.33 \mathrm{~mL} \mathrm{dH} 20$ to a total volume of 10.02 $\mathrm{mL}$. Dispense $6.2 \mu \mathrm{L}$ of the third ligation mixture to each well of the four 384-well PCR plates containing beads. Next add $8.8 \mu \mathrm{L} \backslash(580 \mathrm{pmol})$ from each well of the hybridized third barcode plates to the corresponding wells of the 384-well PCR plates containing the bead and ligation mixture. 26. Repeat 
steps 18-22. The beads can now be stored at $4{ }^{\circ} \mathrm{C}$ for up to one year. In the current form the beads are almost completely double stranded and not yet in the correct form to be used for stLFR. 27. Count the beads with hemocytometer and take out 5 million beads for the QC step. Place the tube with beads onto

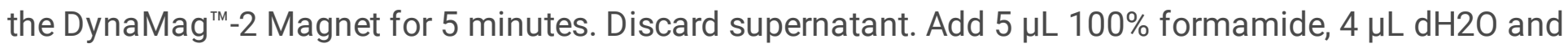
$1 \mu \mathrm{L} 10 \mathrm{X}$ loading buffer. Incubate it at $95^{\circ} \mathrm{C}$ for 3 minutes on a PCR thermocycler. Immediately place on ice for 2 minutes. Place the tube with beads onto the DynaMag ${ }^{\mathrm{TM}}-2$ Magnet for 5 minutes. Collect supernatant, load on a $15 \%$ TBU gel, and run at $200 \mathrm{~V}$ for 40 minutes to check the oligo length and amount $\backslash$ (Figure 2). Alternatively, beads can be examined using a flow cytometer by hybridizing a fluorescently labeled oligo to the 3 ' end of the bead adapter sequence. We typically see about $25 \%$ of the total streptavidin bound sites have a full length constructed adapter sequence. Bead preparation for stLFR To prepare beads for stLFR, they must first be denatured to single stranded DNA and then rehybridized with the bridge oligo. 28. Pipette 500 million constructed barcoded beads from step 26 . of the previous section into a standard $1.5 \mathrm{~mL}$ microcentrifuge tube. 29. Place on DynaMag ${ }^{\mathrm{TM}}-2$ Magnet for 2 minutes to collect beads onto the side of the tube. Remove supernatant. 30 . Add $1 \mathrm{~mL}$ of a $1 \mathrm{X}$ dilution of Buffer D. Vortex briefly and incubate for 2 minutes at room temperature. 31. Place on DynaMag ${ }^{\text {TM }}-2$ Magnet for 2 minutes to collect beads onto the side of the tube. Remove supernatant. 32. Repeat steps 30 and 31 one more time. 33. Wash once in $1 X$ Annealing buffer. Place on DynaMag ${ }^{\text {TM }}-2$ Magnet for 2 minutes to collect beads onto the side of the tube. Remove supernatant. 34. Mix $36 \mu \mathrm{L}$ of $100 \mu \mathrm{M}$ Bridge Oligo, $333.33 \mu \mathrm{L}$ of Annealing Buffer $\backslash(3 \mathrm{X})$, and $630.67 \mu \mathrm{L}$ of $\mathrm{dH} 2 \mathrm{O}$ for a final volume of $1 \mathrm{~mL}$. Add to mixture to beads. Vortex briefly. 35. Incubate at $60^{\circ} \mathrm{C}$ for 5 minutes, and room temperature for 50 minutes. 36. Place on DynaMag ${ }^{\mathrm{TM}}-2$ Magnet for 2 minutes to collect beads onto the side of the tube. Remove supernatant and resuspend in $500 \mu \mathrm{L}$ of Low-Salt Wash Buffer. These beads are now ready for stLFR and can be stored for 3 months at $4{ }^{\circ} \mathrm{C}$. Two transposons stLFR protocol The protocol utilizes two transposons to create hybridization sequences and PCR primer sites along the length of genomic DNA molecules. This is the most simplified and quickest stLFR method, but has potentially $50 \%$ less coverage per long DNA fragment than the $3^{\prime}$ branch ligation protocol. It may be necessary to alter some of the transposon sequence after the mosaic region for compatibility with sequencing technologies other than BGISEQ-500. Check the sequencing primers being used prior to ordering these oligonucleotides. Information on all of the oligonucleotide sequences is available in the supplementary materials. 37. Hybridize the capture transposon oligos by combining $10 \mu \mathrm{L}$ of Transposon $1 \mathrm{~T} \backslash(100 \mu \mathrm{M}), 10 \mu \mathrm{L}$ of TransposonB $\backslash(100 \mu \mathrm{M}), 10 \mu \mathrm{L}$ of Annealing Buffer $\backslash(3 \mathrm{X})$ in the first well of an 8 well PCR strip tube and the non-captured transposon oligos by combining $10 \mu \mathrm{L}$ of Transposon $1 \mathrm{~T} \backslash(100 \mu \mathrm{M}), 10 \mu \mathrm{L}$ of TransposonB $\backslash(100 \mu \mathrm{M}), 10 \mu \mathrm{L}$ of Annealing Buffer $\backslash(3 \mathrm{X})$ in the second well of the same PCR strip tube. 38. Incubate at $70{ }^{\circ} \mathrm{C}$ for 3 minutes followed by a slow ramp of $0.1{ }^{\circ} \mathrm{C} / \mathrm{s}$ to $20^{\circ} \mathrm{C}$ on a PCR thermocycler. Combine the two transposons into the third well of the PCR strip tube. 39. Couple the Tn5 enzyme to the transposon mix by combining $9.6 \mu \mathrm{L}$ of mix transposons with $23.53 \mu \mathrm{L}$ of $\operatorname{Tn} 5 \backslash(13.6 \mathrm{pmol} / \mu \mathrm{L})$, and $46.87 \mu \mathrm{L}$ of Coupling Buffer $\backslash(1 \mathrm{X})$. 40 . Incubate at $30^{\circ} \mathrm{C}$ for 1 hour. Use immediately or store at $-20{ }^{\circ} \mathrm{C}$ for up to 1 month. For optimal performance and consistency between experiments we suggest making aliquots prior to storage. 41. Incorporate transposons into long genomic DNA by combining $12 \mu \mathrm{L}$ of Transposase Buffer $\backslash(5 X), 0.5 \mu \mathrm{L}$ of coupled transposon from step 40 , and $40 \mathrm{ng}$ of DNA in a total 
volume of $60 \mu \mathrm{L}$ in one well of an 8-well strip tube. Note: this amount of DNA and the amount of coupled transposon can be adjusted in this step. It will be necessary to titrate the amount of Tn5 enzyme used as there can be variability between batches. Also, starting with less DNA is possible, but for the purposes of titration it is useful to use $40 \mathrm{ng}$ so that some of the material can be run on an agarose gel to determine the efficiency of transposon incorporation $\backslash$ (see later steps). 42 . Incubate at $55^{\circ} \mathrm{C}$ for 10 minutes. 43 . Transfer $40 \mu \mathrm{L}$ of transposon incorporated material to one well of a new 8-well strip tube. Add $4 \mu \mathrm{L}$ of $1 \%$ SDS and incubate at room temperature for 10 minutes. 44. Load the material from step 43 on a $0.5 X$ TBE $1 \%$ agarose gel and run at $150 \mathrm{~V}$ for 40 minutes. The transposed DNA should run between 200 to 1,500 bp on the gel $\backslash$ (Figure 3). We typically want to see the brightest part of the DNA smear around $600 \mathrm{bp}$, this might be different based on which sequencing technology is chosen. We typically load controls that are put through the same steps but lack the transposon, the Tn5 enzyme, or genomic DNA. If the size of transposon integrated products looks correct proceed to step 45. If not, repeat the steps above but adjust the concentration of the coupling product until the smear is the desired size. 45 . Dilute $1.5 \mu \mathrm{L}$ of the remaining product of step 42 , with $248.5 \mu \mathrm{L}$ of $1 \times$ Hybridization buffer. 46 . Transfer $50 \mu \mathrm{L}$ of beads $\backslash(50$ million) from step 36 to a $1.5 \mathrm{~mL}$ microcentrifuge tube. Place on DynaMag ${ }^{\text {TM }}-2$ Magnet for 2 minutes to collect beads onto the side of the tube. Remove supernatant and resuspend in $250 \mu \mathrm{L}$ of Hybridization Buffer $\backslash(1 \mathrm{X})$. 47. Heat DNA and beads separately at $60^{\circ} \mathrm{C}$ for 30 seconds. 48 . Add $250 \mu \mathrm{L}$ of diluted DNA to the $250 \mu \mathrm{L}$ of beads, mix gently by flicking the bottom of the tube with a finger, and continue incubating at $60^{\circ} \mathrm{C}$ for 10 minutes. Lightly mix the tube every few minutes with your finger. 49 . Place on tube revolver for incubation in oven at $45^{\circ} \mathrm{C}$ for 50 minutes on "oscillating" mode. 50. Make ligation mix by combining $100 \mu \mathrm{L}$ of Ligation Buffer, No MgCl2 $\backslash(10 \mathrm{X}), 2 \mu \mathrm{L}$ of T4 DNA ligase $\backslash(2 \times 106 \mathrm{units} / \mathrm{mL})$, and $398 \mu \mathrm{L}$ of $\mathrm{dH} 2 \mathrm{O}$. Remove tube from rotator and add ligation mix for a total volume of $1 \mathrm{~mL}$. 51 . Incubate on tube revolver for 1 hour on "oscillating" mode at room temperature. 52. Add $110 \mu \mathrm{L}$ of $1 \%$ SDS to tube and incubate for 10 minutes at room temperature. 53. Place on DynaMag ${ }^{\mathrm{TM}}-2$ Magnet for 2 minutes to collect beads onto the side of the tube. Remove supernatant and wash once with $500 \mu \mathrm{L}$ of Low-Salt Wash Buffer and once with $500 \mu \mathrm{L}$ of NEB2 buffer $\backslash(1 \mathrm{X})$. 54. Make capture oligo digestion mix by combining $10 \mu \mathrm{L}$ of NEB2 buffer $\backslash(10 \mathrm{X}), 2 \mu \mathrm{L}$ of UDG $\backslash(5,000 \mathrm{U} / \mathrm{mL}), 3 \mu \mathrm{L}$ of APE1 $\backslash(10,000 \mathrm{U} / \mathrm{mL}), 2 \mu \mathrm{L}$ of Exonuclease $1 \backslash(20,000$ units $/ \mathrm{mL})$, and $83 \mu \mathrm{L}$ of $\mathrm{dH} 2 \mathrm{O}$. Remove wash buffer and add digestion mix to beads. 55 . Vortex lightly to resuspend beads and incubate at $37^{\circ} \mathrm{C}$ for 30 minutes. 56. Place on DynaMag $^{\mathrm{TM}}-2$ Magnet for 2 minutes to collect beads onto the side of the tube. Remove supernatant and wash once with $500 \mu \mathrm{L}$ of Low-Salt Wash Buffer and once with $500 \mu \mathrm{L}$ of PfuCx Buffer $\backslash(1 X)$. 57. Prepare PCR master mix by adding $150 \mu \mathrm{L}$ of PCR mix $\backslash(2 \mathrm{X}), 4 \mu \mathrm{L}$ of PCR Primer $1 \backslash(100 \mu \mathrm{M}), 4 \mu \mathrm{L}$ of PCR primer $2 \backslash(100 \mu \mathrm{M}), 6 \mu \mathrm{L}$ of PfuCx enzyme, and $136 \mu \mathrm{L}$ of dH2O. Preheat the PCR mastermix at $95^{\circ} \mathrm{C}$ for 3 minutes. Place on DynaMag ${ }^{\mathrm{TM}}-2$ Magnet for 2 minutes to collect beads onto the side of the tube. Remove wash buffer and add PCR master mix to beads. 58. Vortex lightly to resuspend beads and cycle PCR reaction with the following conditions: Step $172{ }^{\circ} \mathrm{C} 10$ minutes Step $295^{\circ} \mathrm{C} 10$ seconds Step $358{ }^{\circ} \mathrm{C} 30$ seconds Step $472^{\circ} \mathrm{C} 2$ minutes Step 6 Repeat steps 2-5 10-12 times 59. PCR should result in $500 \mathrm{ng}$ of DNA, run $20 \mathrm{ng}$ of product on a $0.5 \mathrm{X}$ TBE $1 \%$ agarose gel for 40 minutes at $150 \mathrm{~V}$. The material should be a smear with a peak around 500 bp \(Figure 4). 60. Purify PCR product with $300 \mu \mathrm{L}$ of Agencourt XP beads following the manufacturer's protocol. This purified product is now ready to enter the sequencing 
process. Single transposon 3' branch ligation stLFR protocol This protocol is based on the single transposon insertion and novel adapter ligation methods in a DNA gap \(ref) and can enable higher coverage per fragment, which may be important for some sequencing strategies such as de novo assembly. This strategy is slightly more expensive due to additional reagents. It also takes 2.5 hours longer. 61. Hybridize the capture transposon oligos by combining $10 \mu \mathrm{L}$ of Transposon1T $\backslash(100 \mu \mathrm{M}), 10$ $\mu \mathrm{L}$ of TransposonB $\backslash(100 \mu \mathrm{M}), 10 \mu \mathrm{L}$ of Annealing Buffer $\backslash(3 X)$ in the first well of an 8 well PCR strip tube and the $3^{\prime}$ branch ligation adapter by combing $10 \mu \mathrm{L}$ of BranchT $\backslash(100 \mu \mathrm{M}), 10 \mu \mathrm{L}$ of BranchB $\backslash(100 \mu \mathrm{M})$, $10 \mu \mathrm{L}$ of Annealing Buffer $\backslash(3 \mathrm{X})$ in the second well of the same PCR strip tube. 62 . Incubate at $70^{\circ} \mathrm{C}$ for 3 minutes followed by a slow ramp of $0.1^{\circ} \mathrm{C} / \mathrm{s}$ to $20^{\circ} \mathrm{C}$ on a PCR thermocycler. 63 . Couple the Tn 5 enzyme to the transposon by combining $9.6 \mu \mathrm{L}$ of hybridized capture transposon in step 61 with $23.53 \mu \mathrm{L}$ of $\mathrm{Tn} 5$ $\backslash(13.6 \mathrm{pmol} / \mu \mathrm{L})$, and $46.87 \mu \mathrm{L}$ of Coupling Buffer $\backslash(1 \mathrm{X})$. 64 . Incubate at $30^{\circ} \mathrm{C}$ for 1 hour. Use immediately or store at $-20^{\circ} \mathrm{C}$ for up to 1 month. 65 . Follow steps $41-51$. 66. Place on DynaMag ${ }^{\text {TM }}-2$ Magnet for 2 minutes to collect beads onto the side of the tube. Remove supernatant and wash once with $500 \mu \mathrm{L}$ of Low-Salt Wash Buffer. 67. Make adapter oligo digestion mix by combining $10 \mu \mathrm{L}$ of TA Buffer $\backslash(10 \mathrm{X}), 4.5$ $\mu \mathrm{L}$ of Exonuclease I $\backslash(20,000 \mathrm{U} / \mathrm{mL}), 1 \mu \mathrm{L}$ of Exonuclease III $\backslash(100,000 \mathrm{U} / \mathrm{mL})$, and $74.5 \mu \mathrm{L}$ of $\mathrm{dH} 20$. Remove wash buffer and add digestion mix to beads. 68 . Vortex lightly to resuspend beads and incubate on the tube revolver for 10 minutes at $37^{\circ} \mathrm{C}$ on "oscillating" mode. 69 . Add $11 \mu \mathrm{L}$ of $1 \%$ SDS and incubate for 10 minutes at room temperature. 70. Place on DynaMag ${ }^{\mathrm{TM}}-2$ Magnet for 2 minutes to collect beads onto the side of the tube. Remove supernatant and wash once with $500 \mu \mathrm{L}$ of Low-Salt Wash Buffer and once with $500 \mu \mathrm{L}$ of NEB2 buffer $\backslash(1 \mathrm{X})$. 71. Make capture oligo digestion mix by combining $10 \mu \mathrm{L}$ of NEB2 buffer $\backslash(10 X), 2 \mu \mathrm{L}$ of UDG $\backslash(5,000 \mathrm{U} / \mathrm{mL}), 3 \mu \mathrm{L}$ of APE1 $\backslash(10,000 \mathrm{U} / \mathrm{mL})$, and $85 \mu \mathrm{L}$ of $\mathrm{dH} 20$. Remove wash buffer and add digestion mix to beads. 72. Lightly vortex to resuspend beads and incubate at $37^{\circ} \mathrm{C}$ for 30 minutes. 73. Place on DynaMag ${ }^{\mathrm{TM}}-2$ Magnet for 2 minutes to collect beads onto the side of the tube. Remove supernatant and wash once with $500 \mu \mathrm{L}$ of High-Salt Wash Buffer and once with 500 $\mu \mathrm{L}$ of Low-Salt Wash Buffer $\backslash(1 \mathrm{X})$. 74. Prepare SSB binding mix by combining $20 \mu \mathrm{L}$ of SSB binding buffer $\backslash(1 X)$ and $4 \mu \mathrm{L}$ of ET SSB $\backslash(500 \mu \mathrm{g} / \mathrm{mL})$. Remove wash buffer and add SSB binding mix to beads. 75. Vortex lightly to resuspend beads and incubate on the tube revolver for 30 minutes at $37^{\circ} \mathrm{C}$ on "oscillating" mode. 76. Prepare 3' branch ligation mix by combining 33.4 $\mu \mathrm{L}$ of 3' Branch Ligation Buffer $\backslash$ (3X), $18 \mu \mathrm{L}$ of the $3^{\prime}$ branch ligation adapter $\backslash(16.7 \mu \mathrm{M})$ prepared in step $61,2 \mu \mathrm{L}$ of T4 DNA ligase $\backslash$ (2x106 units $/ \mathrm{mL}$ ), and $46.6 \mu \mathrm{L}$ of $\mathrm{dH} 2 \mathrm{O}$. Remove wash buffer and add ligation mix to beads. 77 . Vortex lightly to resuspend beads and incubate on the tube revolver for 2 hours at $25^{\circ} \mathrm{C}$ on "oscillating" mode. 78. Place on DynaMag ${ }^{\mathrm{TM}}-2$ Magnet for 2 minutes to collect beads onto the side of the tube. Remove supernatant and wash once with $500 \mu \mathrm{L}$ of High-Salt Wash Buffer and once with $500 \mu \mathrm{L}$ of PCR buffer $\backslash$ (1X). 79. Prepare PCR master mix by adding $150 \mu \mathrm{L}$ of $2 \mathrm{X}$ PCR buffer, $4 \mu \mathrm{L}$ of PCR Primer $1 \backslash(100 \mu \mathrm{M}), 4$ $\mu \mathrm{L}$ of PCR primer $2 \backslash(100 \mu \mathrm{M}), 6 \mu \mathrm{L}$ of PCR enzyme, and $136 \mu \mathrm{L}$ of dH2O. Remove wash buffer and add PCR master mix to beads. 80 . Vortex lightly to resuspend beads and cycle PCR reaction with the following conditions: Step 195 C 3 minutes Step 295 C 10 seconds Step 358 C 30 seconds Step 472 C 2 minutes Step 5 Repeat steps 2-4 10-12 times 81. Follow steps 59-60 above. Analyzing stLFR data The starting point for this process is a FASTQ file. This is a standard format for read data that is generated by most sequencing technologies. The software we use to deconvolute the barcode information takes the FASTQ 
file and expects 42 bases of the barcode and common adapter sequence to be appended to the end of the first read. It matches the barcode read data to the expected 1536 sequences at each barcode position. The barcoding strategy used by stLFR enables error correction of barcodes that have a single base mismatch. The final output from our software is a FASTQ file with the barcode information appended to the end of the read ID with the format \#Barcode1ID_Barcode2ID_Barcode3ID, where BarcodelD is a number from 0-1536. Zero for a barcode ID means it did not match any of the expected barcode sequences. The software can be downloaded here https://github.com/stLFR/stLFR_read_demux. We recommend using BWA-mem $\backslash($ Li and Durbin 2009) for mapping, GATK \(McKenna et al. 2010) for variant calling, and HapCUT2 $\backslash$ (Edge et al. 2017) for phasing. We also recommend mapping to Hg19 with decoy sequences.

\section{References}

Agent Technologies I. 2015. RecoverEase DNA Isolation Kit. Revision C.0〉(Revision C.0). Amini S, Pushkarev D, Christiansen L, Kostem E, Royce T, Turk C, Pignatelli N, Adey A, Kitzman JO, Vijayan K et al. 2014. Haplotype-resolved whole-genome sequencing by contiguity-preserving transposition and combinatorial indexing. Nat Genet 46\(12): 1343-1349. Ciotlos S, Mao Q, Zhang RY, Li Z, Chin R, Gulbahce N, Liu SJ, Drmanac R, Peters BA. 2016. Whole genome sequence analysis of BT-474 using complete Genomics' standard and long fragment read technologies. Gigascience 5: 8. Drmanac R 2006. Nucleic Acid Analysis by Random Mixtures of Non-Overlapping Fragments. Vol WO 2006/138284. Drmanac R, Peters, B.A., Alexeev, A. 2013. Multiple tagging of individual DNA fragments. Vol WO 2014/145820 A2 \(ed. USPTO). Duitama J, McEwen GK, Huebsch T, Palczewski S, Schulz S, Verstrepen K, Suk EK, Hoehe MR. 2012. Fosmid-based whole genome haplotyping of a HapMap trio child: evaluation of Single Individual Haplotyping techniques. Nucleic Acids Res 40\(5): 2041-2053. Edge P, Bafna V, Bansal V. 2017. HapCUT2: robust and accurate haplotype assembly for diverse sequencing technologies. Genome Res 27\(5): 801-812. Fan HC, Wang J, Potanina A, Quake SR. 2011. Whole-genome molecular haplotyping of single cells. Nat Biotechnol 29\(1): 51-57. Gulbahce N, Magbanua MJM, Chin R, Agarwal MR, Luo X, Liu J, Hayden DM, Mao Q, Ciotlos S, Li Z et al. 2017. Quantitative Whole Genome Sequencing of Circulating Tumor Cells Enables Personalized Combination Therapy of Metastatic Cancer. Cancer Res 77 (16): 4530-4541. Hellner K, Miranda F, Fotso Chedom D, Herrero-Gonzalez S, Hayden DM, Tearle R, Artibani M, KaramiNejadRanjbar M, Williams R, Gaitskell K et al. 2016. Premalignant SOX2 overexpression in the fallopian tubes of ovarian cancer patients: Discovery and validation studies. EBioMedicine 10: 137-149. Kitzman JO, Mackenzie AP, Adey A, Hiatt JB, Patwardhan RP, Sudmant PH, Ng SB, Alkan C, Qiu R, Eichler EE et al. 2011. Haplotype-resolved genome sequencing of a Gujarati Indian individual. Nat Biotechnol 29 (1): 59-63. Kuleshov V, Xie D, Chen R, Pushkarev D, Ma Z, Blauwkamp T, Kertesz M, Snyder M. 2014. Whole-genome haplotyping using long reads and statistical methods. Nat Biotechnol 32\(3): 261-266. Li H, Durbin R. 2009. Fast and accurate short read alignment with BurrowsWheeler transform. Bioinformatics 25\(14): 1754-1760. Ma L, Xiao Y, Huang H, Wang Q, Rao W, Feng Y, Zhang K, Song Q. 2010. Direct determination of molecular haplotypes by chromosome microdissection. Nat Methods 7\(4): 299-301. Mao Q, Chin R, Xie W, Deng Y, Zhang W, Xu H, Yu Zhang R, Shi Q, Peters EE, 
Gulbahce N et al. 2018. Advanced Whole-Genome Sequencing and Analysis of Fetal Genomes from Amniotic Fluid. Clinical chemistry. Mao Q, Ciotlos S, Zhang RY, Ball MP, Chin R, Carnevali P, Barua N, Nguyen S, Agarwal MR, Clegg T et al. 2016. The whole genome sequences and experimentally phased haplotypes of over 100 personal genomes. Gigascience 5\(1): 1-9. McElwain MA, Zhang RY, Drmanac R, Peters BA. 2017. Long Fragment Read \(LFR) Technology: Cost-Effective, High-Quality Genome-Wide Molecular Haplotyping. Methods Mol Biol 1551: 191-205. McKenna A, Hanna M, Banks E, Sivachenko A, Cibulskis K, Kernytsky A, Garimella K, Altshuler D, Gabriel S, Daly M et al. 2010. The Genome Analysis Toolkit: a MapReduce framework for analyzing next-generation DNA sequencing data. Genome Res 20 (9): 1297-1303. Peters BA, Kermani BG, Alferov O, Agarwal MR, McElwain MA, Gulbahce N, Hayden DM, Tang YT, Zhang RY, Tearle R et al. 2015. Detection and phasing of single base de novo mutations in biopsies from human in vitro fertilized embryos by advanced whole-genome sequencing. Genome Res 25\(3): 426-434. Peters BA, Kermani BG, Sparks AB, Alferov O, Hong P, Alexeev A, Jiang Y, Dahl F, Tang YT, Haas $\mathrm{J}$ et al. 2012. Accurate whole-genome sequencing and haplotyping from 10 to 20 human cells. Nature 487\(7406): 190-195. Peters BA, Liu J, Drmanac R. 2014. Co-barcoded sequence reads from long DNA fragments: a cost-effective solution for "perfect genome" sequencing. Frontiers in genetics 5: 466. Picelli S, Bjorklund AK, Reinius B, Sagasser S, Winberg G, Sandberg R. 2014. Tn5 transposase and tagmentation procedures for massively scaled sequencing projects. Genome Res 24\(12): 2033-2040. Schaaf CP, Gonzalez-Garay ML, Xia F, Potocki L, Gripp KW, Zhang B, Peters BA, McElwain MA, Drmanac R, Beaudet AL et al. 2013. Truncating mutations of MAGEL2 cause Prader-Willi phenotypes and autism. Nat Genet 45\(11): 1405-1408. Selvaraj S, J RD, Bansal V, Ren B. 2013. Whole-genome haplotype reconstruction using proximity-ligation and shotgun sequencing. Nat Biotechnol 31\(12): 1111-1118. Suk EK, McEwen GK, Duitama J, Nowick K, Schulz S, Palczewski S, Schreiber S, Holloway DT, McLaughlin S, Peckham H et al. 2011. A comprehensively molecular haplotype-resolved genome of a European individual. Genome Res 21\(10): 1672-1685. Walker RF, Ciotlos S, Mao Q, Chin R, Drmanac S, Barua N, Agarwal MR, Zhang RY, Li Z, Wu MKY et al. 2017. Clinical and genetic analysis of a rare syndrome associated with neoteny. Genetics In Medicine. Wang O, Chin R, Cheng X, Wu M, Mao Q, Tang J, Sun Y, Lam H, Chen D, Zhou Y et al. 2018. Single tube bead-based DNA co-barcoding for cost effective and accurate sequencing, haplotyping, and assembly. bioRxiv. Zhang F, Christiansen L, Thomas J, Pokholok D, Jackson R, Morrell N, Zhao Y, Wiley M, Welch E, Jaeger E et al. 2017. Haplotype phasing of whole human genomes using bead-based barcode partitioning in a single tube. Nat Biotechnol 35\(9): 852-857. Zhang K, Zhu J, Shendure J, Porreca GJ, Aach JD, Mitra RD, Church GM. 2006. Long-range polony haplotyping of individual human chromosome molecules. Nat Genet 38\(3): 382-387. Zheng GX, Lau BT, Schnall-Levin M, Jarosz M, Bell JM, Hindson CM, Kyriazopoulou-Panagiotopoulou S, Masquelier DA, Merrill L, Terry JM et al. 2016. Haplotyping germline and cancer genomes with high-throughput linkedread sequencing. Nat Biotechnol.

\section{Acknowledgements}

We would like to acknowledge the ongoing contributions and support of all Complete Genomics and BGIShenzhen employees, in particular the many highly skilled individuals that work in the libraries, reagents, 
and sequencing groups that make it possible to generate high quality whole genome data. This work was supported in part by the Shenzhen Peacock Plan \(NO.KQTD20150330171505310). B.A.P. is a recipient of and this work was partially supported by the Research Fund for International Young Scientists, National Natural Science Foundation of China \(31550110216).

\section{Figures}

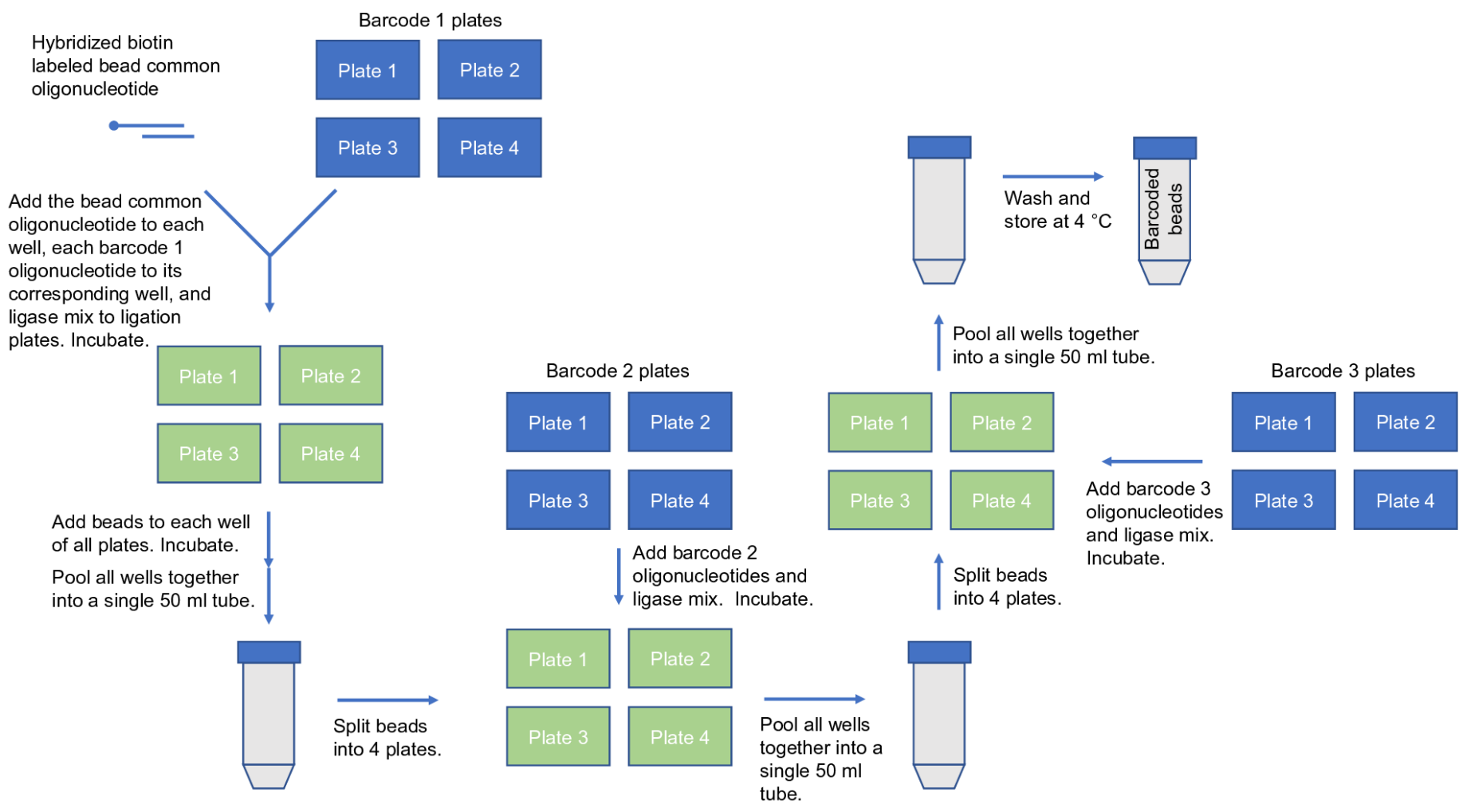

\section{Figure 1}

Barcoded bead assembly Barcoded beads are generated through successive rounds of split and pool synthesis with streptavidin beads and three sets of barcoded oligos. The number of barcodes is flexible. In this example we used three sets of 1,536 10 base barcodes generating a total of $~ 3.6$ billion different barcodes. Each bead contains approximately 400,000 identical copies of the barcode. 


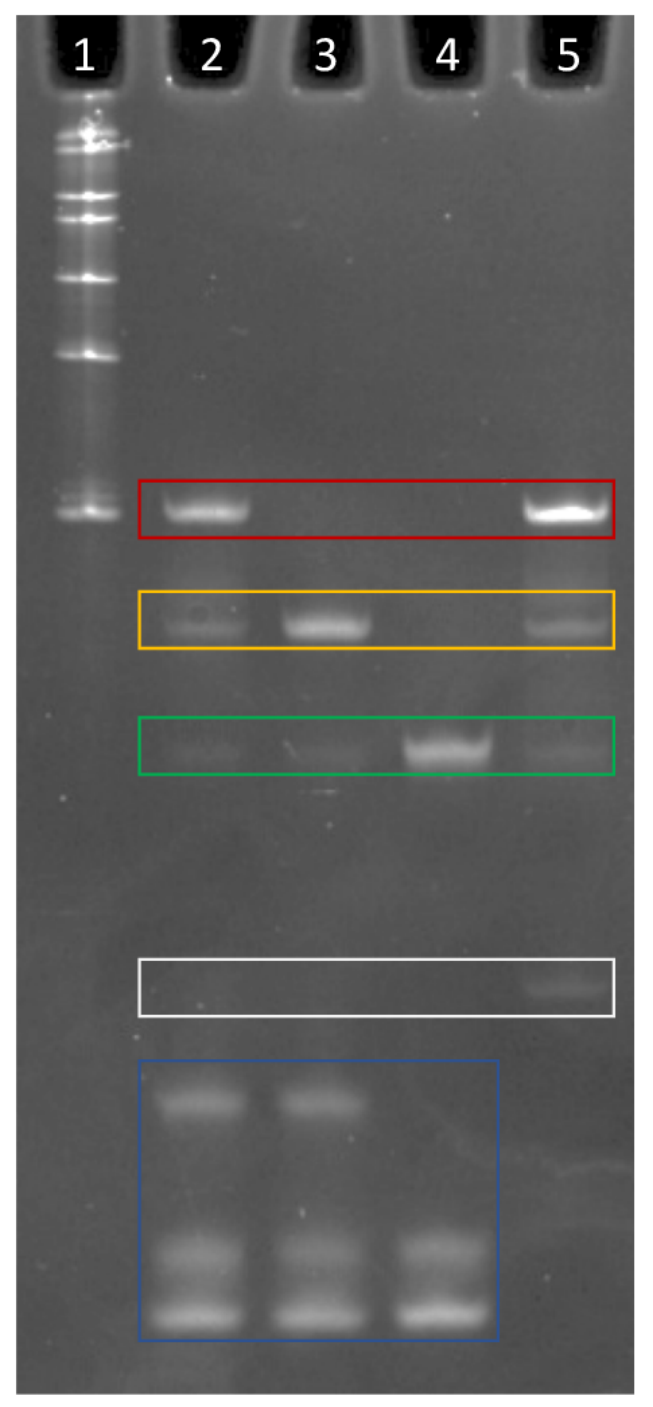

\section{Figure 2}

Acrylamide gel of barcode assembly. Barcoded oligos were released from the beads at various steps in the assembly process and run on a 15\% TBU gel. The lanes are as follows: (1) $1.5 \mathrm{uL}$ of 20 fold diluted RiboRuler Low Range Ladder, (2) Product from step \#26, (3) product from step \# 24, (4) product from step \#19, (5) product from step \#36. The red box shows where the full length barcode adapter should run on the gel. The orange box shows were the barcode adapter should run after two barcodes are ligated 
together. The green box shows were the adapter should run after ligation of the common sequence to the first barcode. The bridge oligo should run where the white box is located. The non ligated adapter helper oligos are found within the blue box.

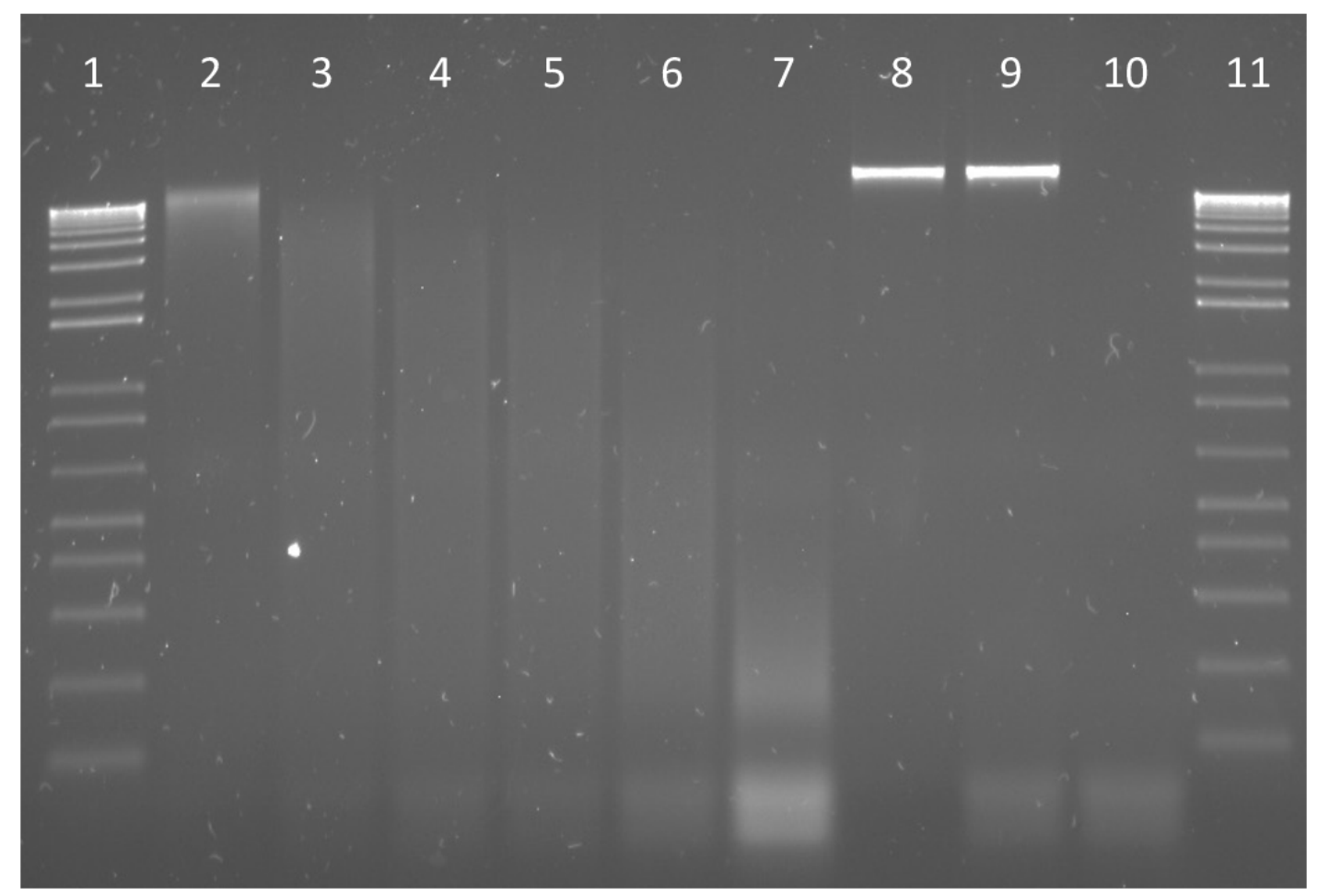

\section{Figure 3}

Agarose gel of transposon integrated DNA Transposon integrated DNA was run on a 1\% TBE gel for 40 minutes at $150 \mathrm{~V}$. Except for the DNA ladders the following are transposon integration reactions and are 
listed by what change for the protocol described in steps 38-43. The lanes are as follows: (1) $40 \mathrm{ng}$ of 1 $\mathrm{Kb}$ Plus ladder, (2) $0.2 \mathrm{pmol}$ of coupling product, (3) $0.8 \mathrm{pmol}$ of coupling product, (4) $1.2 \mathrm{pmol}$ of coupling product, (5) $1.5 \mathrm{pmol}$ of coupling product, (6) 2 pmol of coupling product, (7) 8 pmol of coupling product, (8) no transposon, (9) no Tn5 enzyme, (10) no genomic DNA, (11) $40 \mathrm{ng}$ of $1 \mathrm{~Kb}$ Plus ladder. We typically use 1.2 pmols (lane 4 ) of coupling product for our experiments.

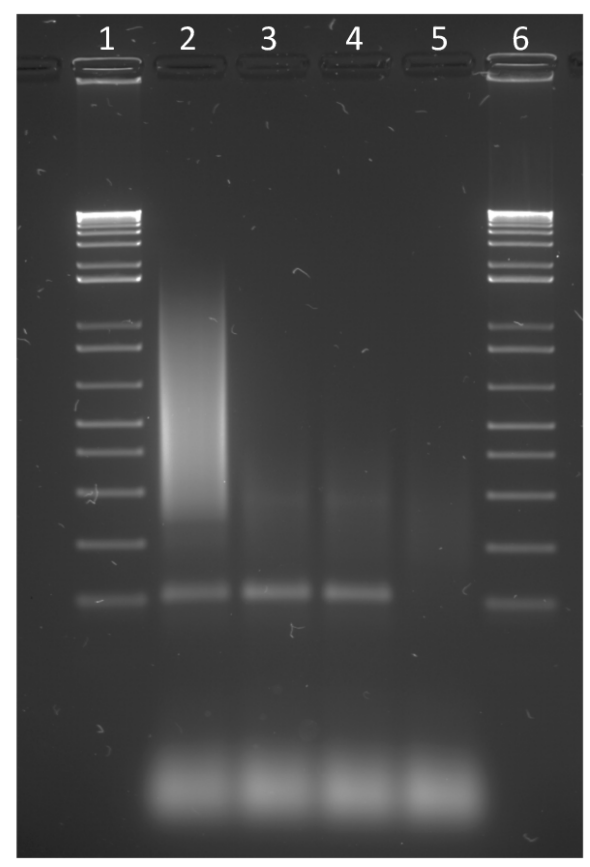

\section{Figure 4}

Agarose gel of transposon integrated DNA Transposon integrated DNA was run on a 1\% TBE gel for 40 minutes at $150 \mathrm{~V}$. Except for the DNA ladders the following are transposon integration reactions and are listed by what change for the protocol described in steps 61-79. The lanes are as follows: (1) $40 \mathrm{ng}$ of 1 $\mathrm{Kb}$ Plus ladder, (2) final library product, (3) no DNA, transposon and beads only control, (4) no DNA, no transposon, beads only control, (5) no DNA, no transposon, no beads, water only control, (6) $40 \mathrm{ng}$ of $1 \mathrm{~Kb}$ Plus ladder. Excess capture adapter that has disassociated from the beads can be seen as a 100 bp band on the gel. Excess PCR primers are visible at the bottom of the gel.

\section{Supplementary Files}

This is a list of supplementary files associated with this preprint. Click to download.

- supplement0.pdf

- supplement0.xlsx 